Historic, archived document

Do not assume content reflects current scientific knowledge, policies, or practices. 

Forest Service
Intermountain

Research Station

Ogden, UT 84401

Research Paper

INT-340

April 1985

(0405
Stands Treated with

Herbicides

in the Western

United States

Roy O. Harniss

Dale L. Bartos

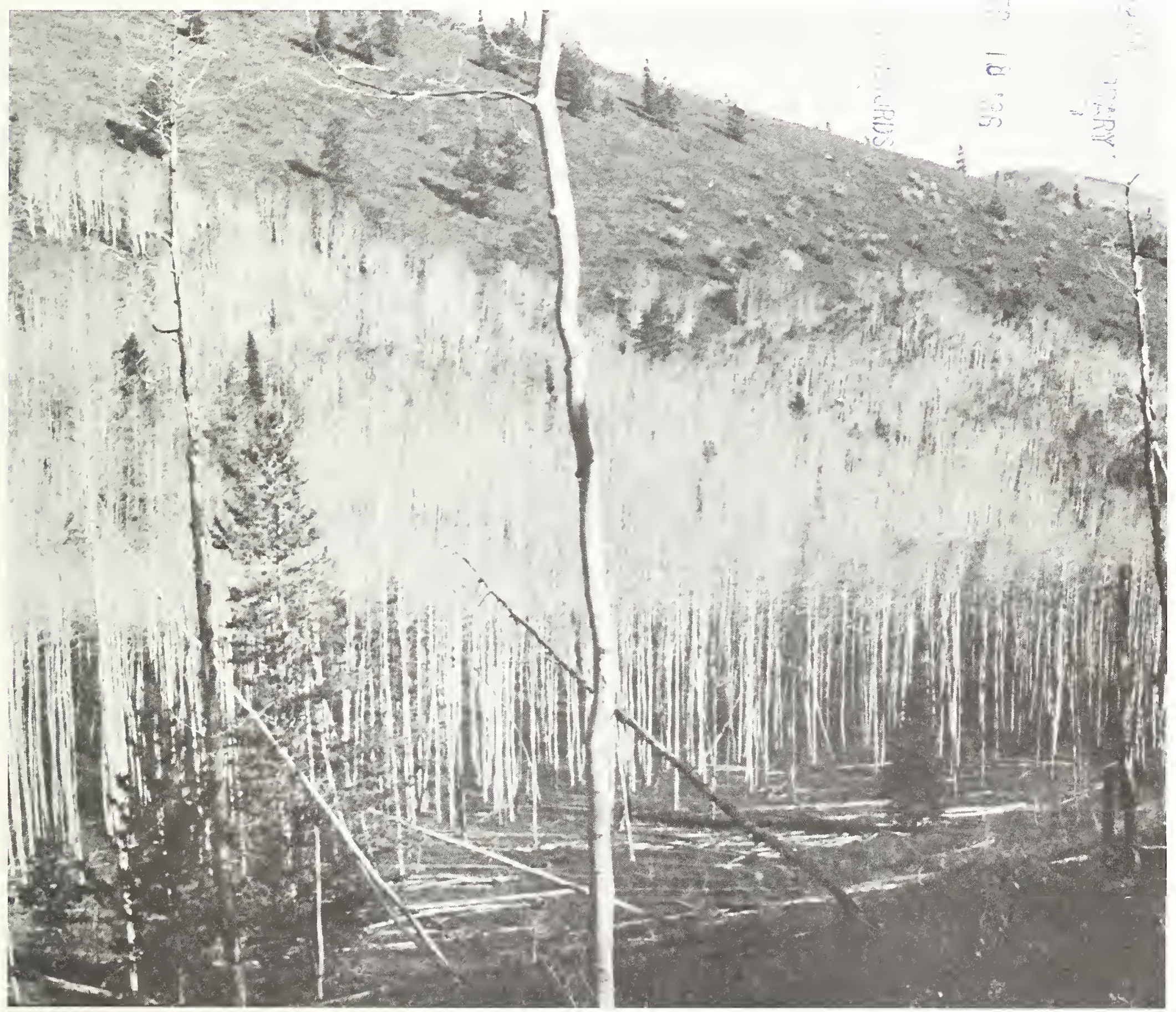




\section{THE AUTHORS}

ROY O. HARNISS is a range scientist at the Forestry Sciences Laboratory, Logan, UT. He has conducted ecological research in sagebrush and aspen vegetation. He has a B.S. degree from Washington State University, Pullman, and an M.S. degree from Utah State University, Logan.

DALE L. BARTOS is an operations research analyst with the Intermountain Station, Ogden, UT. For 13 years (1972-84) he was a range scientist associated with the aspen ecosystem project at Logan, UT. Bartos holds B.S. and M.S. degrees from Fort Hays Kansas State University, and a Ph.D. degree in range science from Colorado State University. His principal research interests are systems modeling and ecological research.

\section{RESEARCH SUMMARY}

Aspen stands sprayed with herbicide were compared to aspen stands not sprayed in the Western United States. The herbicide 2,4-D mixed at about $2 \mathrm{lb} / a c r e$ $(2.2 \mathrm{~kg} / \mathrm{ha}$ ) with water or diesel was most commonly used. Average number of live aspen trees over 2 inches $(5 \mathrm{~cm})$ diameter; stand height, age, and diameter; basal area; and disease incidence were higher in the unsprayed stands. Average number of suckers was generally higher in the sprayed stands. The exception to sufficient suckering occurred where small isolated aspen clones were heavily grazed. There were more grass species and fewer forb species in the understory of the sprayed stands. Grass and total vegetation production was also higher in the sprayed stands. Vegetative cover was greater in the sprayed stands, but organic matter was deeper on the unsprayed plots.

\section{PESTICIDE PRECAUTIONARY STATEMENT}

This publication reports research involving pesticides. It does not contain recommendations for their use, nor does it imply that the uses discussed here have been registered. All uses of pesticides must be registered by appropriate State and/or Federal agencies before they can be recommended.

CAUTION: Pesticides can be injurious to humans, domestic animals, desirable plants, and fish or other wildlife-if they are not handled or applied properly. Use all pesticides selectively and carefully. Follow recommended practices for the disposal of surplus pesticides and pesticide containers.

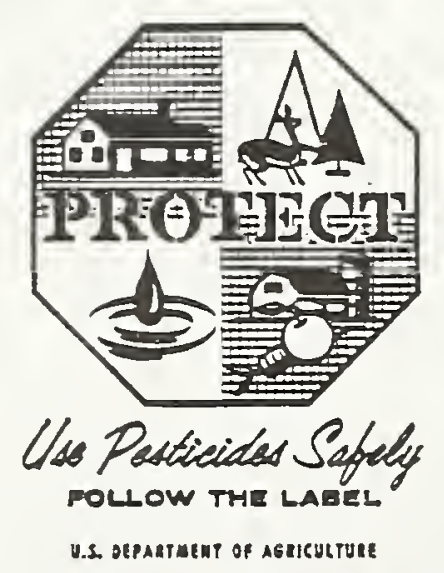

The use of trade, firm, or corporation names in this publication is for the information and convenience of the reader. Such use does not constitute an official endorsement or approval by the U.S. Department of Agriculture of any product or service to the exclusion. of others that may be suitable. 


\title{
Survey of Aspen Stands Treated with Herbicides in the Western United States
}

\author{
Roy O. Harniss \\ Dale L. Bartos
}

\section{INTRODUCTION}

Western aspen (Populus tremuloides Michx.) forests are valued by resource managers for the multiple-use values of water, forage, wildlife habitat, and esthetics (DeByle 1981). Aspen stands are being managed by cutting and burning to rejuvenate aspen and to get a better age distribution of stands (Bartos 1981). Herbicide spraying (fig. l) is now beginning to be used on aspen in areas inaccessible or unsuited for cutting or burning. However, little information is available to the forest manager in the Western United States on what to expect from the use of herbicides or how they could be used to rejuvenate mature aspen stands.

Between 1965 and 1967 in central Utah, 470 acres (190 ha) were repeatedly sprayed with $2,4-\mathrm{D}$ and $2,4,5-\mathrm{T}$ (a total of six times during the growing season) in an attempt to convert the deep-rooted aspen and the associated communities to a more shallow-rooted grass type to increase water production (Robinson 1971). Aspen were virtually eliminated from the site immediately after spraying, and grass production increased approximately 10 times, in part because of aerial seeding. However, other problems arose such as mass slumping, accelerated erosion, and damage to big game habitat. Robinson (1971) indicated that "massive applications of herbicides to aspen and associated plant communities are not recommended at present since the full ecological impact of such treatment is not known." Several years after spraying, suckers $10 \mathrm{ft}(3 \mathrm{~m})$ tall were abundant.

In 1958, personnel at the Bridger-Teton National Forest sprayed 9,000 acres ( 3645 ha) of sagebrush, which included aspen stringers, on the Upper Green River in western Wyoming. According to Lester (1972), the 2,4-D treatment "eliminated or injured" the aspen and some conifers. Bartos and Lester (1984) examined these aspen stands 22 years later and found abundant aspen trees on the sprayed areas. Forbs were still fewer in number of species, and there were no differences in grasses when compared to unsprayed aspen.

We decided to evaluate aspen stands that were accidentally or purposefully treated with herbicides by comparing the overstory and understory of treated and adjacent untreated stands throughout the Intermountain and Rocky Mountain area.

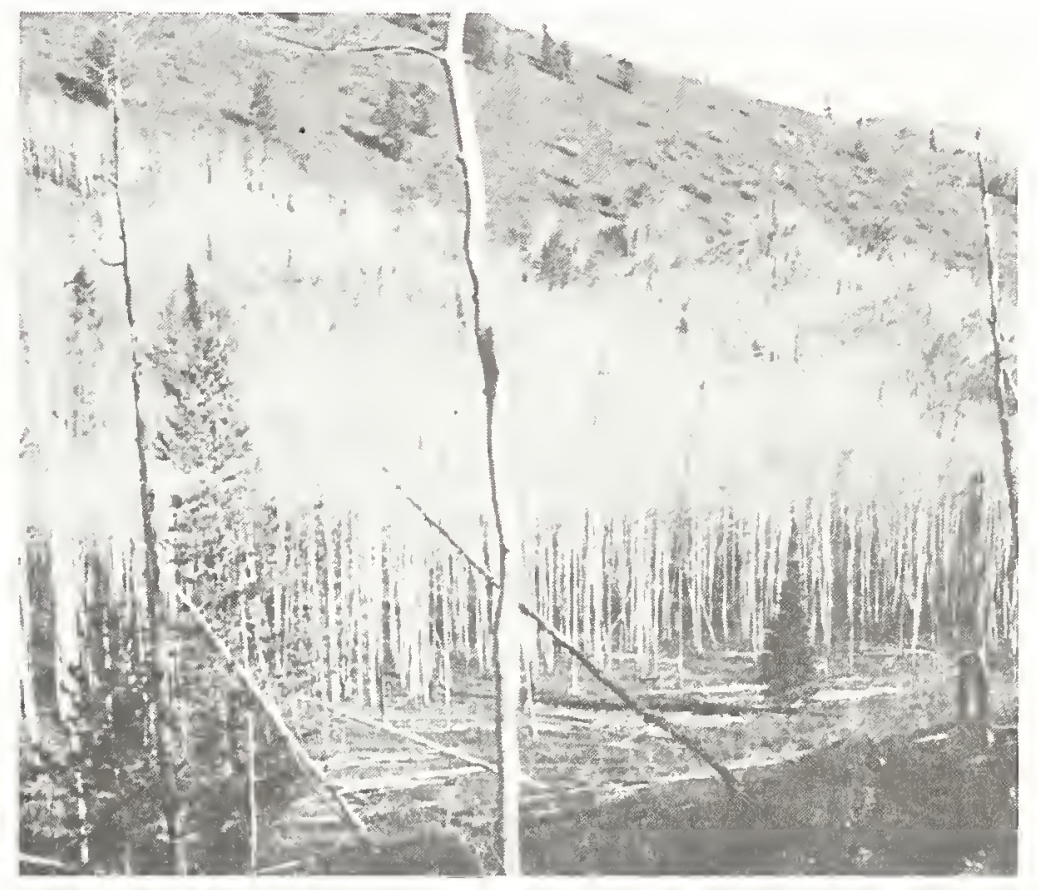

Figure 1.-Herbicide sprayed stand of aspen in southeastern Idaho after 1 year.

\section{METHODS}

National Forest personnel in the Western United States identified aspen stands treated with herbicides in conjunction with sagebrush, aspen, or conifer-release spraying projects. Stands were sampled if sprayed and unsprayed comparisons in proximity were about 1 acre (0.4 ha) and had information on the spray treatment. Spray information consisted of herbicide type, rate, carrier (water or diesel fuel), time of year, method of application, and treatment success on target species.

Stands were sampled at two levels of intensity. In stands selected for intensive sampling, 33- by 33-ft (10by $10-\mathrm{m}$ ) plots were placed on the contour of the slope in relatively uniform and representative sprayed and unsprayed vegetation. Environmental attributes recorded were: elevation, aspect, slope percentage, and depth of soil organic layer, melanized layer, and parent material. Tree data determined by species on the entire 
sample plot consisted of: diameter at breast height (d.b.h.) of live and dead trees over 2 inches $(5 \mathrm{~cm})$ d.b.h.; stem count of live and dead reproduction in classes of less than 20 inches $(0.5 \mathrm{~m})$ tall, 20 inches to $6.6 \mathrm{ft}$ $(0.5 \mathrm{~m}$ to $2 \mathrm{~m})$ tall, and greater than $6.6 \mathrm{ft}(2 \mathrm{~m})$ tall up to 2 inches $(5 \mathrm{~cm})$ d.b.h., and number of stumps and diseased trees (primarily conks). Species numbers, composition, and frequency of the understory were determined by 33 nested frequency frames in each sample plot (U.S. Department of Agriculture 1983). Vegetation litter, rock, and bare ground were estimated from six points per frequency frame on the sample plot. Understory biomass was determined by both clipping and estimating current year's growth, up to $4.9 \mathrm{ft}(1.5 \mathrm{~m})$ high, by vegetation categories. Four sets of microplots, were distributed randomly on the $1,076 \mathrm{ft}^{2}\left(100 \mathrm{~m}^{2}\right)$ macroplot. Each set consisted of five circular $5.4 \mathrm{ft}^{2}$ $\left(0.5 \mathrm{~m}^{2}\right)$ microplots clustered so that the biomass of four could be estimated as a percentage of the fifth, which was then clipped. The clipped vegetation was dried at least 48 hours in an oven at $158^{\circ} \mathrm{F}\left(70^{\circ} \mathrm{C}\right)$ and weighed for biomass. Percentages of the shrub, grass, and forb components were estimated on all five microplots. The dry weight biomass by vegetation categories is based on 20 microplots per stand. Photographs of the overstory and understory vegetation were taken on all plots.

On the plots sampled less intensively, the tree and environmental data were determined the same as on the more intensively sampled plots. The understory species cover was ocularly estimated on the entire $1,096 \mathrm{ft}^{2}$
(100 $\left.\mathrm{m}^{2}\right)$ plot. The sets of microplots to determine understory biomass were estimated by vegetation categories.

More sprayed than unsprayed stands were sampled because variation was expected to be greater in the sprayed stands. All plots were used in an analysis using the one-tailed $t$-test for independent means.

\section{RESULTS AND DISCUSSION}

We sampled 17 sprayed areas that met our criteria in Idaho, Wyoming, Colorado, and Utah (fig. 2); 34 sprayed plots and 22 unsprayed plots for comparison were sampled (table 1). Sagebrush was the target species for most of the herbicide treatments (table 1). Aspen was sprayed for stand regeneration on four areas and for conifer release on two areas. The herbicide most commonly used was $2,4-\mathrm{D}$ in high volatile butyl ester formulations mixed with water or diesel. The indicated rates of $2 \mathrm{lb} /$ acre $(2.2 \mathrm{~kg} / \mathrm{ha})$ are possibly higher than that actually applied in the aspen stands associated with sagebrush because of drift and volatilization. Quality control and equipment capabilities would also be factors in nontarget applications. Most of the sagebrush spray projects in which aspen was hit used fixed-wing aircraft in the late 1950's and early 1960's. The rarity of sprayed aspen stands in the 1970's when sagebrush was the target species coincides with the use of helicopter and low-volatile esters. Volatilization effects on nontarget species were reduced markedly when low volatile esters replaced the high volatile esters.

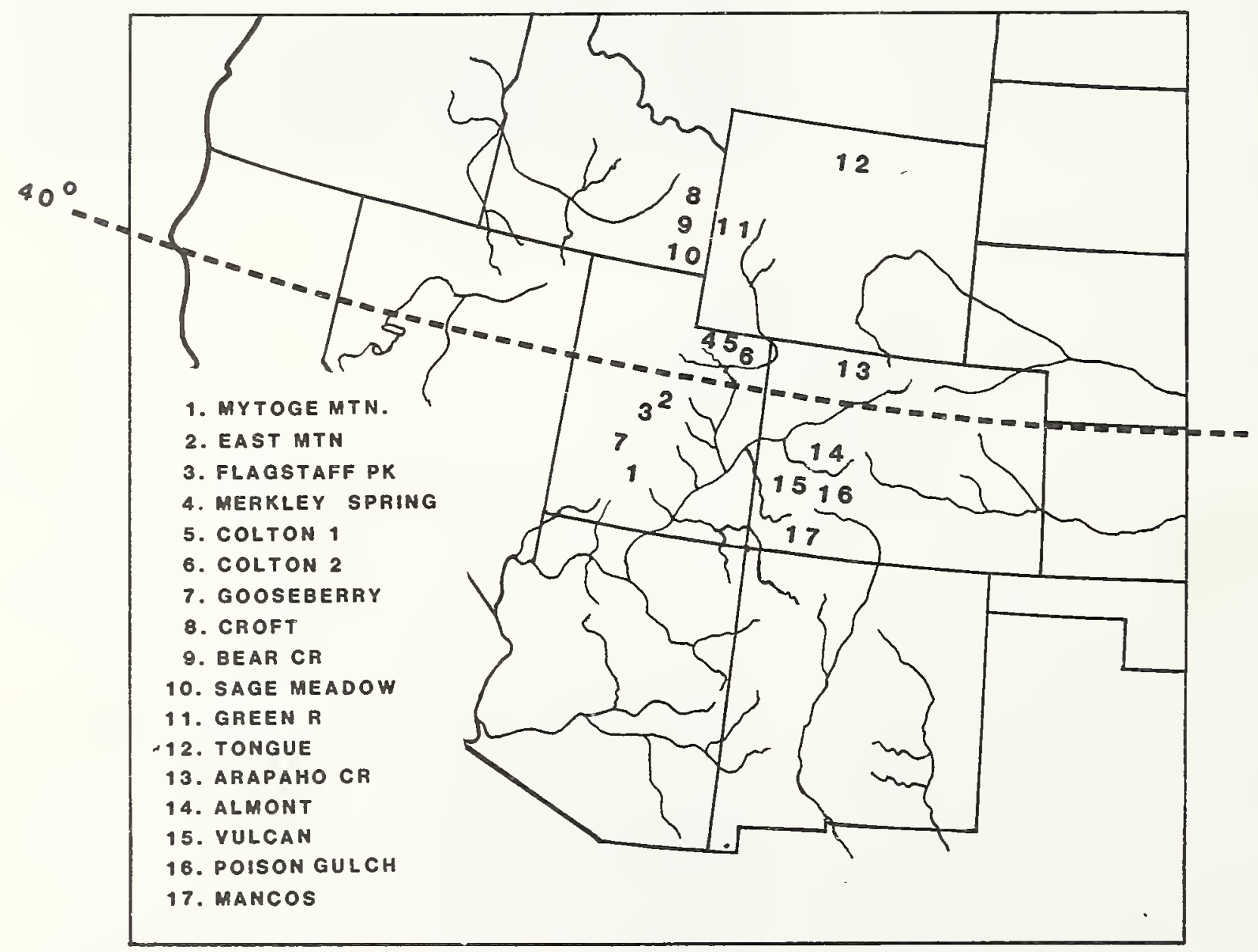

Figure 2.--Locations of herbicide treatments in Western United States. 


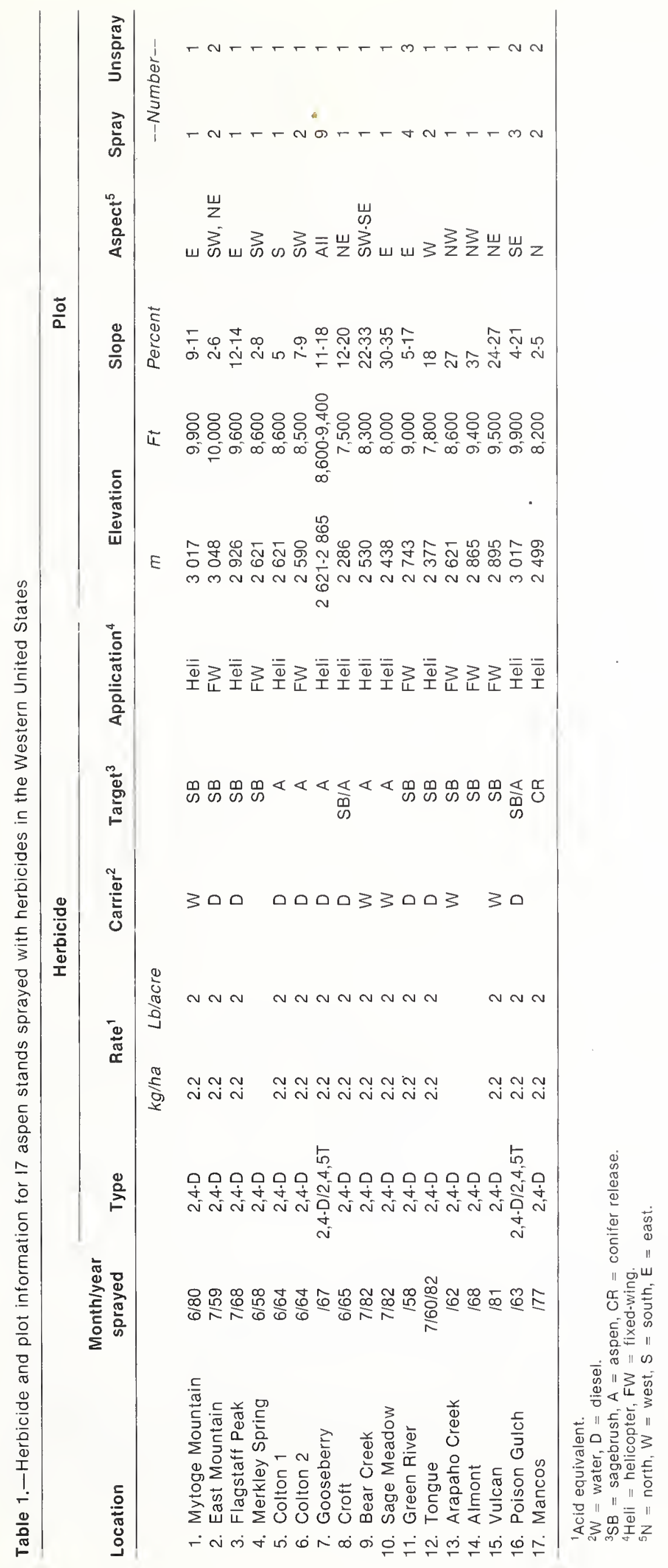


Differences occurred between the sprayed and unsprayed stands in the direction to be expected (table 2). Average number of live trees over 2 inches $(5 \mathrm{~cm})$ d.b.h., stand height, stand age, stand diameter, basal area, and disease incidence were higher in the unsprayed stands. Average number of suckers was generally higher in the sprayed stands, especially in the over $6.5-\mathrm{ft}(2-\mathrm{m})$ category. The larger variation evident in the sprayed data is due partly to the variation in the number of years since spraying. The range in the number of live trees and stand attributes for the unsprayed stands is about the expected range for aspen forests in the West (Baker 1925; Mueggler and Campbell 1982). However, average stand height, diameter, and basal area appear low for aspen. Perhaps most of the aspen stands associated with sagebrush spraying had drier site condition or poorer stand quality. Suckering on all sprayed stands was generally sufficient for rejuvenating the stand (fig. 3). The exception to sufficient suckering occurred in areas where the aspen clone was small

Table 2.- Tree and stand attributes for 34 sprayed and 22 unsprayed aspen stands

\begin{tabular}{|c|c|c|c|c|c|c|}
\hline \multirow[b]{2}{*}{ Variable } & \multirow[b]{2}{*}{ Units } & Sprayed & Unsprayed & \multirow[b]{2}{*}{ t Prob } & \multicolumn{2}{|c|}{ Range } \\
\hline & & $\bar{x} \pm s^{1}$ & $\bar{x} \pm s$ & & Sprayed & Unsprayed \\
\hline \multicolumn{7}{|l|}{ Trees } \\
\hline Live $>5 \mathrm{~cm}$ & no/0.01 na ${ }^{2}$ & $12.1 \pm 13.0$ & $21.0 \pm 10.3$ & 0.0046 & $0-53$ & 9.50 \\
\hline Dead $>5 \mathrm{~cm}$ & no/0.01 ha & $9.0 \pm 9.9$ & $6.7 \pm 4.3$ & .1608 & 0.42 & 1.16 \\
\hline Stumps & no/0.01 ha & $14.5 \pm 9.5$ & $3.1 \pm 4.2$ & .0000 & 0.33 & $0-14$ \\
\hline \multicolumn{7}{|l|}{ Suckers } \\
\hline Live $<0.5 \mathrm{~m}$ & no/0.01 ha & $32.4 \pm 59.4$ & $16.5 \pm 19.0$ & .1155 & 0.212 & 0.80 \\
\hline Dead $<0.5 \mathrm{~m}$ & no/0.01 ha & $4.0 \pm 14.0$ & $1.0 \pm 2.5$ & .1632 & 0.80 & 0.11 \\
\hline Live $0.5-2 \mathrm{~m}$ & no/0.01 ha & $54.8 \pm 99.4$ & $23.0 \pm 28.9$ & .0753 & $0-548$ & $0-121$ \\
\hline Dead $0.5 \cdot 2 \mathrm{~m}$ & no/0.01 ha & $11.0 \pm 11.7$ & $4.9 \pm 8.3$ & .0200 & $0-37$ & $0-34$ \\
\hline Live $>2 \mathrm{~m}-5 \mathrm{~cm}$ d.b.h. & no/0.01 ha & $39.9 \pm 45.1$ & $5.2 \pm 12.3$ & .0005 & 0.131 & 0.57 \\
\hline Dead $>2 \mathrm{~m}-5 \mathrm{~cm}$ d.b.h. & no/0.01 ha & $6.3 \pm 9.6$ & $2.1 \pm 2.6$ & .0233 & $0-42$ & $0-8$ \\
\hline \multicolumn{7}{|l|}{ Stands } \\
\hline Height & $m$ & $8.7 \pm 5.7$ & $12.6 \pm 3.4$ & .0010 & 0.20 & $6-20$ \\
\hline Age & years & $47.7 \pm 39.4$ & $83.7 \pm 21.8$ & .0001 & $0-129$ & $38-117$ \\
\hline Average d.b.h. & $\mathrm{cm}$ & $7.9 \pm 5.6$ & $15.0 \pm 3.3$ & .0000 & 0.19 .6 & $8.4-20.8$ \\
\hline Basal area & $\mathrm{m}^{2} / 0.01$ ha & $0.102 \pm 0.115$ & $0.368 \pm 0.161$ & .0000 & 0.0 .4366 & $0.1208-0.7399$ \\
\hline Disease & $P / A^{3}$ & $0.029 \pm 0.172$ & $0.318 \pm 0.477$ & .0010 & $0-1$ & 0.1 \\
\hline
\end{tabular}

${ }^{\top}$ Average \pm standard deviation.

${ }^{2}$ Multiply by 100 for numbers/hectare; 40.47 for numbers/acre.

${ }^{3}$ Presence or absence.

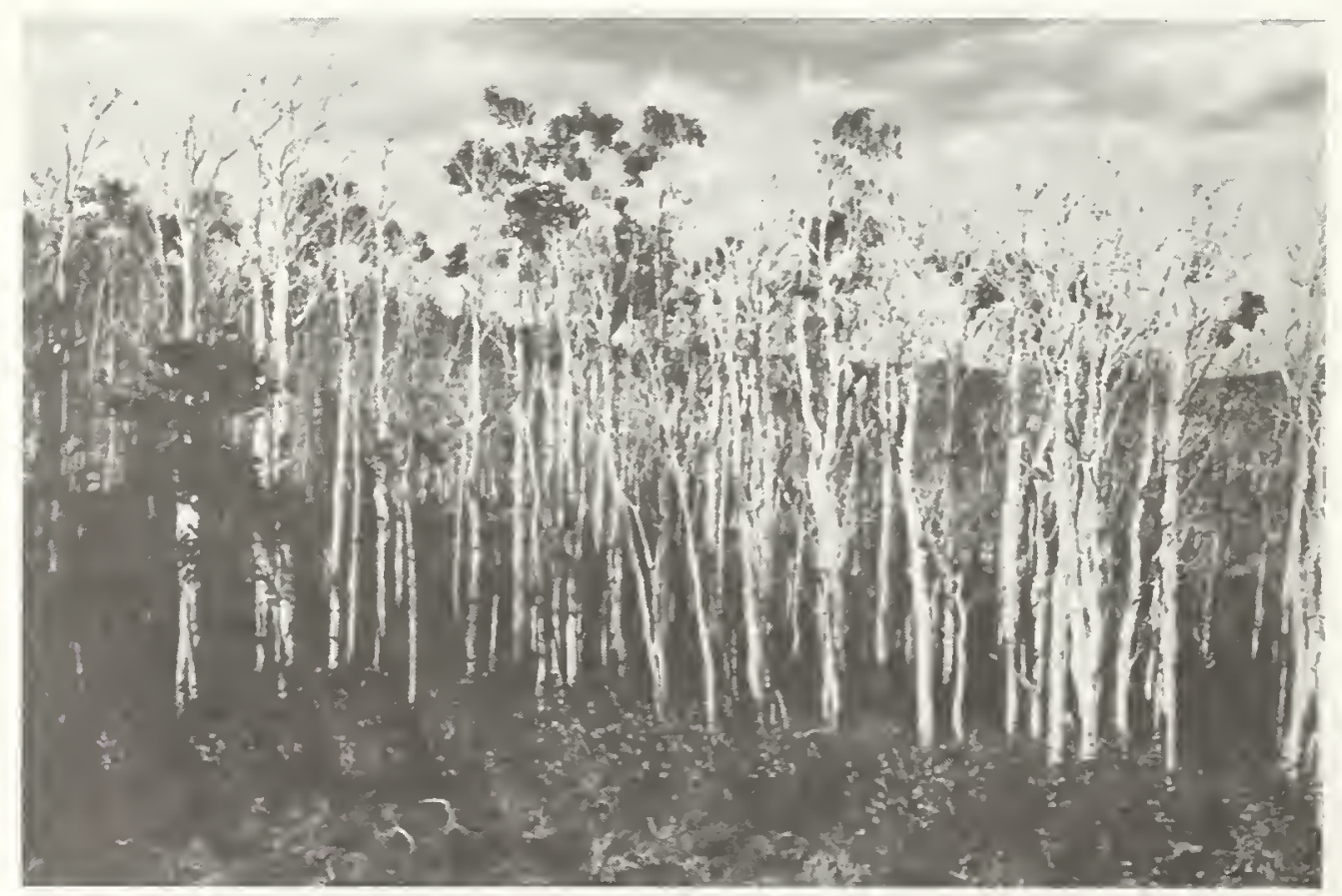

Figure 3. - Abundant regeneration of aspen

3 years after herbicide spraying. 


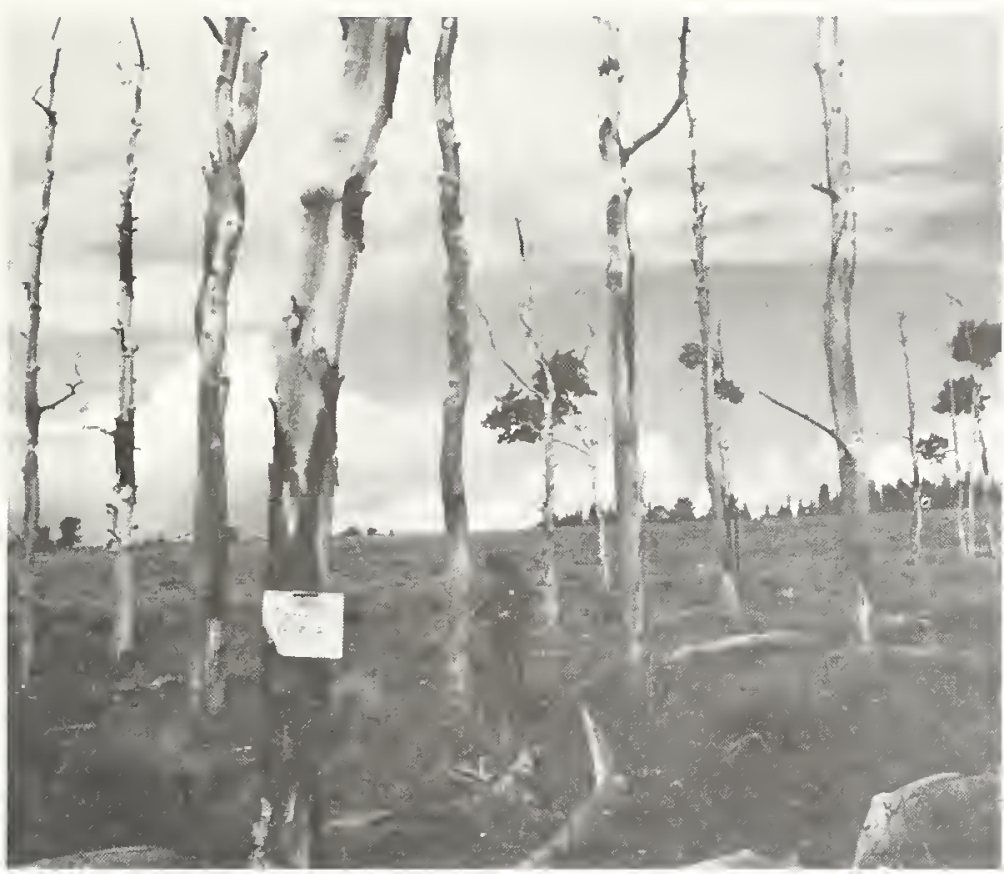

Figure 4.-Isolated aspen stand treated with herbicide with no regeneration of aspen because of heavy grazing by deer and cattle.

(less than 1 acre [0.4 ha]), isolated, and grazed heavily by livestock or big game (fig. 4).

The understory composition had more grass and fewer forbs in the sprayed than in the unsprayed stands (table 3). Grass and total vegetation production was higher in the sprayed than in the unsprayed stands. Shrub numbers were slightly lower in the sprayed stands. Vegetation cover was greater on the sprayed plots, but the organic matter was deeper on the unsprayed plots, possibly due to undisturbed litter from aspen and understory categories. These results agree with expectations of broadleaf herbicide treatments (Anderson 1977). Forbs and shrubs would sharply decrease early while the grasses would increase after spraying. We found that these effects still show 20 or more years after treatment.

Based on the results of our observations and related literature, considerations for the use of herbicides on aspen that appear appropriate are:

1. The purpose for the herbicide treatment should be clearly identified. Aspen regeneration requires less herbicide and different timing than conifer site preparation and release.

2. The use of $2,4-\mathrm{D}$ at a rate of $2 \mathrm{lb} /$ acre $(2.2 \mathrm{~kg} / \mathrm{ha})$ acid equivalent, low volatile mixed with a water carrier, kills most aspen overstory and initiates aspen regeneration. Lower rates of 1 to $1.5 \mathrm{lb} / \mathrm{acre}(1.1$ to $1.6 \mathrm{~kg} / \mathrm{ha})$ may be effective in checking the aspen overstory and initiating suckering. However, this needs to be tested. Dicamba and 2,4-D mixtures have been recommended for Populus spp. control (Hamel 1983). These should be used mostly for conifer site preparations. Glyphosate (Roundup ${ }^{\circledR}$ ) is being used experimentally in southern Utah in the fall for conifer release in stands with abun. dant aspen suckers, Ribes spp., or both.

3. Herbicides are most effective for stimulating aspen regeneration and conifer site preparation when applied soon after aspen reaches the full leaf stage. For conifer release, herbicides should be applied 1 to 3 weeks before aspen leaf fall to reduce herbicide damage to the conifer.

4. Spraying large openings in the aspen canopy should be avoided to reduce damage to shrubs and forbs, especially where aspen regeneration is the goal. Slight to moderate reductions of shrubs and forbs beneath the aspen should be expected when spraying aspen.

Table 3.-Understory vegetation and soil attributes for 34 sprayed and 22 unsprayed aspen stands

\begin{tabular}{|c|c|c|c|c|c|c|}
\hline \multirow[b]{2}{*}{ Variable } & \multirow[b]{2}{*}{ Units } & Sprayed & Unsprayed & \multirow[b]{2}{*}{ t Prob } & \multicolumn{2}{|c|}{ Range } \\
\hline & & $\bar{x} \pm s$ & $\bar{x} \pm s$ & & Sprayed & Unsprayed \\
\hline \multicolumn{7}{|l|}{ Composition } \\
\hline Shrub & Percent & $22.5 \pm 17.7$ & $23.1 \pm 14.3$ & 0.4419 & $1.1-73.9$ & $4.5-56.6$ \\
\hline Grass & Percent & $47.5 \pm 21.3$ & $33.9 \pm 15.7$ & .0063 & $8.8-86.7$ & $5.8-64.3$ \\
\hline Forb & Percent & $31.8 \pm 17.9$ & $43.0 \pm 18.0$ & .0129 & $2.6-58.3$ & $9.9-76.2$ \\
\hline \multicolumn{7}{|l|}{ Weight } \\
\hline Shrub & $\mathrm{kg} / \mathrm{ha}$ & $296.1 \pm 303.1$ & $284.0 \pm 255.9$ & .4390 & $2.5 \cdot 1,147.9$ & $29.5-956.0$ \\
\hline Grass & $\mathrm{kg} / \mathrm{ha}$ & $585.7 \pm 471.3$ & $400.8 \pm 449.8$ & .0764 & $6.4-1,845.1$ & $17.5-2,018.8$ \\
\hline Forb & $\mathrm{kg} / \mathrm{ha}$ & $410.8 \pm 343.8$ & $393.4 \pm 217.6$ & .4167 & $20.8-1,078.9$ & $70.0-832.5$ \\
\hline Total & $\mathrm{kg} / \mathrm{ha}$ & $1,292.9 \pm 600.6$ & $1,078.3 \pm 548.7$ & .0925 & $241.9-2,351.2$ & $211.2-2,539.4$ \\
\hline \multicolumn{7}{|l|}{ Numbers } \\
\hline Shrub & N/0.01 ha & $4.0 \pm 1.8$ & $4.9 \pm 1.4$ & .0287 & $2 \cdot 9$ & $3 \cdot 8$ \\
\hline Grass & N/0.01 ha & $5.7 \pm 2.0$ & $5.9 \pm 1.8$ & .4049 & $3-10$ & $1-8$ \\
\hline Forb & N/0.01 ha & $11.0 \pm 4.6$ & $11.9 \pm 4.9$ & .2354 & $2 \cdot 22$ & $4-20$ \\
\hline Total & N/0.01 ha & $20.6 \pm 6.1$ & $22.6 \pm 5.7$ & .1111 & $12-31$ & $12 \cdot 34$ \\
\hline \multicolumn{7}{|l|}{ Cover } \\
\hline Vegetal & Percent & $81.0 \pm 16.8$ & $73.6 \pm 19.1$ & .0729 & $43-100$ & $30-98$ \\
\hline Litter & Percent & $18.2 \pm 16.5$ & $24.4 \pm 18.3$ & .1052 & 0.65 & $0-70.0$ \\
\hline Rock & Percent & $0.6 \pm 1.6$ & $1.7 \pm 3.3$ & .0713 & $0-7$ & $0-11.1$ \\
\hline Bare ground & Percent & $0.4 \pm 0.9$ & $0.8 \pm 1.5$ & .1558 & $0-3.6$ & $0-5$ \\
\hline \multicolumn{7}{|l|}{ Soils } \\
\hline Organic & $\mathrm{cm}$ & $4.2 \pm 1.6$ & $5.8 \pm 2.8$ & .0317 & $2 \cdot 8$ & $2-12$ \\
\hline$A$ & $\mathrm{~cm}$ & $25.1 \pm 14.8$ & $23.5 \pm 11.8$ & .3650 & $3.8-60$ & $3.8-53$ \\
\hline $\mathrm{B}$ & $\mathrm{cm}$ & $40.1 \pm 17.4$ & $32.4 \pm 12.8$ & .1204 & $15-70$ & $15-59$ \\
\hline
\end{tabular}




\section{REFERENCES}

Anderson, Wood Powell. Weed science: principles. New York: West Publishing Company; 1977. 598 p.

Baker, Frederick S. Aspen in the Central Rocky Mountain Region. Department Bulletin 1291.

Washington, DC: U.S. Department of Agriculture, Forest Service: 1925.47 p.

Bartos, Dale L. Changes in aspen and associated species resulting from manipulation by burning and cutting.

In: DeByle, Norbert V., ed. Situation management of two intermountain species: aspen and coyotes: part 1, aspen: Proceedings of a symposium; 1981 April 23-24; Logan, UT. Logan, UT: Utah State University, College of Natural Resources; 1981: 77-87.

Bartos, Dale L.; Lester, James E. Effects of 2,4-D on a Populus tremuloides community in the western United States 22 years after treatment. Great Basin Naturalist. $44(3): 459-467 ; 1984$.

DeByle, Norbert V. Aspen and its management: an introduction. In: DeByle, Norbert V., ed. Situation management of two intermountain species: aspen and coyotes: part 1, aspen: Proceedings of a symposium; 1981 April 23-24; Logan. UT. Logan, UT: Utah State University, College of Natural Resources; 1981: 5-14.
Lester, James E. The effects of livestock grazing on the response of high mountain vegetation determined from a study of net production and utilization. Laramie, WY: University of Wyoming; 1972. 105 p. Ph.D. dissertation.

Hamel, Dennis R. Forest management chemicals. Agriculture Handbook 585. Washington, DC: U.S. Department of Agriculture, Forest Service; 1983. $645 \mathrm{p}$.

Mueggler, Walter F.; Campbell, Robert B., Jr. Aspen community types on the Caribou and Targhee National Forests in southeastern Idaho. Research Paper INT-294. Ogden, UT: U.S. Department of Agriculture, Forest Service, Intermountain Forest and Range Experiment Station; 1982. 32 p.

Robinson, Max E. Sheep Creek water evaluation project-a study of vegetative type conversion for water yield improvement. 1971. Unpublished report supplied to authors by Fishlake National Forest, Forest Service, U.S. Department of Agriculture, Richfield, UT.

U.S. Department of Agriculture, Forest Service. Range analysis handbook. FSH 2209.21 R-4. Ogden, UT: U.S. Department of Agriculture, Forest Service, Intermountain Region: 1983.

Harniss, Roy O.; Bartos, Dale L. Survey of aspen stands treated with herbicides in the Western United States. Research Paper INT-340. Ogden, UT: U.S. Department of Agriculture, Forest Service, Intermountain Research Station; 1985. $6 \mathrm{p}$.

Aspen stands sprayed with herbicides had higher numbers of aspen suckers than adjacent unsprayed stands. Understory production was higher due to more grass production in the sprayed stands. While the composition of forb species was lower, the number of grass species was higher on sprayed stands than on unsprayed stands. Vegetative cover was greater on the sprayed plots, but organic matter was deeper on the unsprayed plots. These results agree with expectations of broadleaf herbicide treatments.

KEYWORDS: Populus tremuloides, trembling aspen, spraying, understory, 2,4-D, management 